UDC 378: 004.9+004.5

\author{
Oksana B. Morgulets \\ Doctor of Economics, Professor of Department of Entrepreneurship and Business, \\ Director of Staff Training Management Centre \\ Kyiv National University of Technologies and Design, Kyiv, Ukraine \\ ORCID ID 0000-0001-6530-1478 \\ morgulets_oks@ukr.net
}

Tetiana M. Derkach

Doctor of Pedagogical Sciences, Chair of Professional Education in Technologies and Design

Kyiv National University of Technologies and Design, Kyiv, Ukraine

ORCID ID 0000-0003-1087-8274

derkach.tm@knutd.edu.ua

\title{
INFORMATION AND COMMUNICATION TECHNOLOGIES MANAGING THE QUALITY OF EDUCATIONAL ACTIVITIES OF A UNIVERSITY
}

\begin{abstract}
The article highlights the results of the practical application of modern information and communication technologies in the management of institutions of higher education on the example of the Kyiv National University of Technology and Design (KNUTD). The constituents of the quality management system of educational activity are considered. The subsystems of the automated control system of educational activity of the university have been characterised and analysed. The key elements of the information systems use dare the following electronic databases: students and their academic performance; results of employment; students' satisfaction with educational programs; distribution of the teaching load; teachers' performance; learning and teaching resources, facilities, equipment and their cost; other indicators of university activity. In addition to the popular application packages, such as "iZETA", "The System of FinanciallyOriented Management of Higher Education Institutions", and "Anti-Plagiarism", the software products developed by KNUTD are described. Namely, the "Schedule" package allows one to form directories focused on the drawing up of class schedules which are accessible to all divisions. The software "Electronic Journal" provides monitoring of learning outcomes and prompt response to the failure of individual students; it serves for the formation of final control mark sheets, the evaluation of academic success rates of university students, etc. The electronic rating system "RTS rating" is used for the evaluation of research and teaching staff activity according to the results of their work in the reported year. The modular environment of the University's educational process, based on the Moodle distance learning platform, is described. It accumulates the teaching and methodological support necessary for conducting educational activities. The results of the research are of practical value since the implementation of the considered software products is capable of improving the quality and effectiveness of the management of educational activities of higher education institutions.
\end{abstract}

Keywords: information and communication technologies; automated control system; quality management system; institution of higher education; educational activities quality assurance system; management of education quality.

\section{INTRODUCTION}

Problem statement and analysis of recent research and publications. The primary objective of the educational activity of institutions of higher education (IHE) is high-quality training of competitive specialists to meet the needs of society and the labour market in Ukraine. The management system for institutions of higher education (MS-IHE) should include, as its part, a quality management system (QMS) which is aimed at achieving results in accordance with the objective of high-quality education to meet the needs, expectations and demands of all stakeholders [1-3]. Various components of the MS-IHE can be integrated with the QMS into an integrated system using some common elements, such as information and 
communication technologies (ICTs). The implemented ICTs provide technological support to various aspects of the operation of an IHE [4]. The integration simplifies planning, allocating resources, identifying additional goals, and evaluating the overall performance of the institution.

Systematic investigations conducted by T. Poiasok, N. Morze, O. Kuzminska, O. Hlazunova, V. Hrytsenkoand other authors were devoted to the effectiveness of implementing ICT to ensure the quality of educational activities of an IHE. Based on their results, the following critical issues can be formulated in this field:

- The need for regular upgrading of means, technologies and methods of ICT application at all stages of training [5, 6];

- Ensuring a high level of digital competency for all participants in the educational process [7];

- Introduction of an open infomedia at the management level of an IHE, and ensuring an efficient and safe infrastructure, unification, coordination between different platforms, etc. $[4,8]$;

- Adoption of e-learning as a way of realising the tasks of formal education, and expanding its use in non-formal education, foreigners' training and adult education [9];

- Quality assurance on the basis of regular analysis of the impact of ICT on the training at the national and international levels, and ensuring the implementation of international quality standards $[10,11]$.

One may conclude from the analysis of publications that Ukraine is as yet at the stage of formation of ICT-related components of a QMS. The problem of the effective implementation of ICT requires further research, first of all, in the context of automation of the processes of planning, organisation and control of educational activities in an IHE.

The goal of the article is to analyse the results of the implementation of ICT as common components of MS-IHE and QMS at the Kyiv National University of Technology and Design (KNUTD).

\section{METHODOLOGY}

The following methods are used to realise the paper goal: analysis and synthesis to define the problem, collecting and processing facts, and drawing conclusions; generalisation and comparison to determine the causality of the phenomena under study; questionnaire and expert survey to describe the state-of-the-art use of ICT in the educational process of KNUTD.

\section{RESULTS AND DISCUSSION}

The QMS of KNUTD consists of a set of interconnected elements; their interaction is aimed at ensuring a high level and permanent improvement of the quality of educational activities. Figure 1 represents a general view of the QMS of KNUTD [12]. The main elements of the QMS are as follows: the strategy of continuous improvement of the quality of educational activity, policy in the field of quality, planning, assurance, organisation, motivation, monitoring and assessment of the system objects.

The primary criterion for measuring and evaluating educational activities is the quality of an educational product, namely the quality of educational services proper, teaching and educational materials, research works and trained specialists. At the same time, the quality of material and technical support and the variety of educational processes also affect the 
educational product as a result of scholarly activity. Therefore, the principal objects of the quality of educational activity should be resources, educational processes and their outcomes.

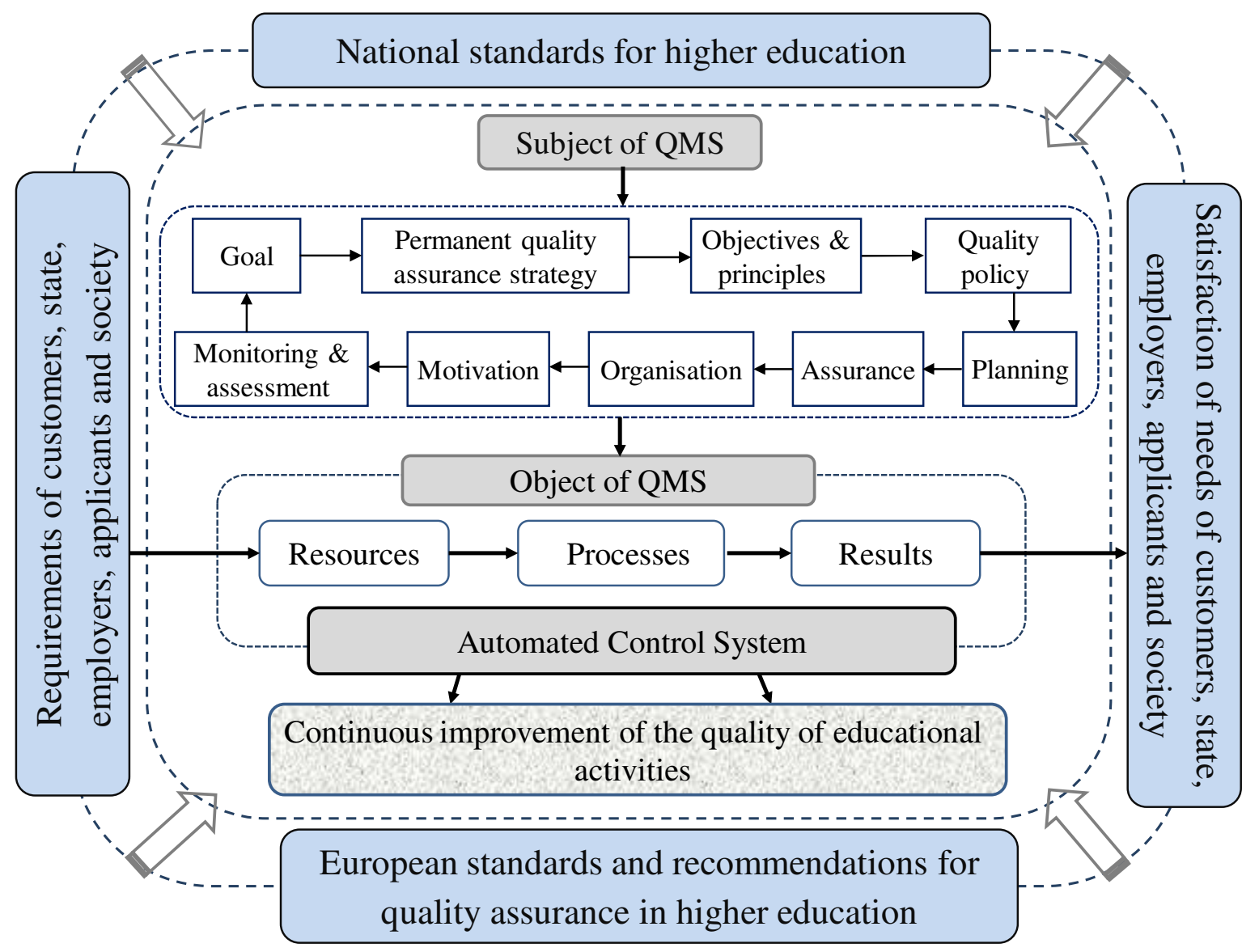

Fig. 1 Quality Management System for the educational activities at KNUTD

The effectiveness of the functioning of the QMS at any IHE is affected by external and internal factors. The main external factors include the requirements and needs of customers, students, employers, the state and society, as well as national and European standards for quality assurance in higher education. Internal factors are the effectiveness of management, including the planning, organisation and control of quality assurance procedures. The subjective aspect, including the attitude of participants in the educational process to the quality of education and their responsibility for the maintenance of acceptable quality, is also of importance. Therefore, the culture of educational activity existing at a university and the level of self-examination and self-control play an essential role.

A mechanism for ensuring the quality of educational activities on the basis of an automated control system (ACS) was developed to manage data flows and control automation of processes occurring at KNUTD (Fig. 2).

The ACS is based on an information and communication system that describes the methods and procedures which provide the collection, analysis and storage of relevant data for the effective management and quality assurance of educational activities. The management personnel, research and teaching staff (RTS) and students have been identified as the subjects of the QMS. They vary in their involvement in managing the quality of educational activities, affecting its components, but everyone is interested in its continuous improvement. The objects of the QMS are the main components of scholarly activity: resources, educational processes and their outcomes. 


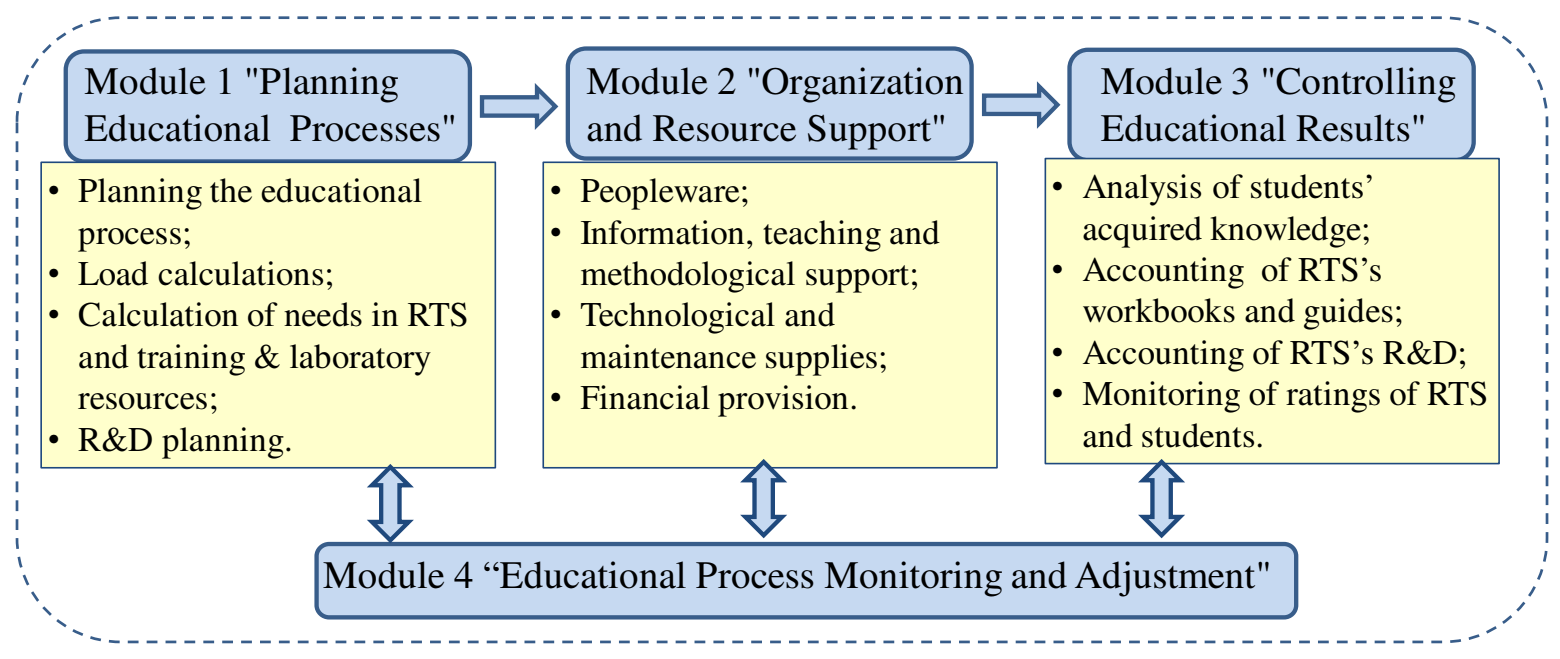

Fig. 2 Modular scheme of an automated control system forthe educational activities at KNUTD

The critical elements of information systems are electronic databases: student population and academic performance indicators; results of employment and satisfaction of students with educational programs; planning and accounting of the teaching load; effectiveness of lecturers; accounting of teaching and methodological resources; accounting of facilities, equipment and their costs; key performance indicators of higher education, etc.

Table 1 characterises the subsystems of the ACS from the standpoint of individual processes in the educational activity which are used at KNUTD. Special application packages are used to carry out accounting of the condition and movement of students, personnel and financial flows, rational use of the existing technological, material and technical resources, educational and laboratory resources, etc.

Table 1

Process subsystems of the ACS for the educational activity atanIHE (on the example of KNUTD)

\begin{tabular}{|l|l|l|}
\hline ACS subsystem & \multicolumn{1}{|c|}{ Automation object } & \multicolumn{1}{c|}{ Characteristics } \\
\hline ISEED & $\begin{array}{l}\text { Student population, } \\
\text { educational documents, } \\
\text { etc. }\end{array}$ & $\begin{array}{l}\text { Integrated State Electronic Educational Database (ISEED) is a } \\
\text { state electronic register of subjects of educational activity, } \\
\text { educational documents, student's cards, etc. }\end{array}$ \\
\hline iZETA & $\begin{array}{l}\text { Curricula, the workload } \\
\text { of RTS }\end{array}$ & $\begin{array}{l}\text { Formation of directories of specialities, educational programs, } \\
\text { lists of disciplines, etc. Calculation of the planned workload } \\
\text { of departments, its distribution between RTS, accounting and } \\
\text { reporting. Automation of the corresponding document } \\
\text { circulation, informational and analytical support of all } \\
\text { KNUTD divisions }\end{array}$ \\
\hline Schedule $(*)$ & Learning load of students & $\begin{array}{l}\text { Drawing up a plan of student lessons, RTS's workloads and } \\
\text { technology charts of classroom availability }\end{array}$ \\
\hline MEEP & $\begin{array}{l}\text { Educational and } \\
\text { methodological support } \\
\text { electronic database which contains a set of electronic teaching } \\
\text { and learning complexes for all disciplines and other electronic } \\
\text { educational resources }\end{array}$ \\
\hline $\begin{array}{l}\text { Electronic } \\
\text { Journal }(*)\end{array}$ & $\begin{array}{l}\text { Academic performance } \\
\text { of students }\end{array}$ & $\begin{array}{l}\text { Recording students' academic performance and the quality of } \\
\text { learning outcomes, building students' academic success rating }\end{array}$ \\
\hline RTSRating $(*)$ & $\begin{array}{l}\text { Results of activity of } \\
\text { RTS }\end{array}$ & $\begin{array}{l}\text { Accounting and evaluation of educational, methodological, } \\
\text { scientific and organisational work of RTS during the reporting } \\
\text { period }\end{array}$ \\
\hline
\end{tabular}




\begin{tabular}{|l|l|l|}
\hline ACS subsystem & \multicolumn{1}{|c|}{ Automation object } & \multicolumn{1}{c|}{ Characteristics } \\
\hline Anti-Plagiarism & $\begin{array}{l}\text { Quality of scientific } \\
\text { works }\end{array}$ & Plagiarism check of academic works of students and RTS \\
\hline $\begin{array}{l}\text { Financial } \\
\text { Management }\end{array}$ & Resource support & $\begin{array}{l}\text { Record of maintenance supplies, people ware and financial } \\
\text { provision of educational activity in IHE }\end{array}$ \\
\hline
\end{tabular}

(*) programs developed by KNUTD

The Integrated State Electronic Education Database (ISEED)is one of the means, without which educational activity is impossible. The database is a state electronic register, the primary purpose of which is to provide stakeholders of educational activity with information about educational institutions, qualifications and scientific degrees, results of independent external performance assessments, the course of entrance campaigns, students' ID cards, and other information in the field of education.

A package of applied programs «iZETA» (developed by V.V. Kulibaba, Poltava University of Economics and Trade [13]) is used for planning, organisation, management and control of the educational process at KNUTD. The system is intended for the creation, maintenance, processing and preservation of information related to the educational process; automation of document circulation in planning, organisation, management and control; information-analytical support of all divisions of an educational institution. The system covers all stages from the formation of curricula to the creation of accounting data of the pedagogical work performed by the university's RTS.

The software product was developed by client/server technology. The database server uses a Database Management System (DBMS) MySQL which ensures high reliability of data storage and integrity [13]. Initial data are formed through a system of directories. Such a complex allows one to accumulate the following information in the database: a list of specialities and codes of groups; index of departments and structural divisions of the institution; lecture-room stock; records of academic disciplines; lists of regular and freelance appointments; personal data of RTS; templates for printed reports, etc.

Class scheduling is one of the tasks of the high-quality organisation of educational process at IHEs. The application package "Schedule", adapted for the needs of the university, is developed and used at KNUTD. This information system is an example of a separate component of the general ACS of educational activity. It is incorporated into the ACS with the help of built-in means for data export-import. The system of administration of rights of access to information allows different department officers to create directories containing information used in scheduling of classes and open them for use by colleagues in other departments.

One of the main requirements for creating a class schedule electronic subsystem is its further development and integration into a single information space, as well as into the common university database. In this regard, the database MS SQL SERVER was taken as the basis of the subsystem "Schedule". The query language is Transact-SQL. The following programming languages were used to create the system: C\#, HTML5 and CSS3. The primary project administration tool is the management system ASP.NET MVC.

The modular environment for educational process (MEEP) at KNUTD is an objectoriented dynamic learning environment developed by the university and based on the free learning platform for the organisation of distance education MOODLE (the Modular ObjectOriented Dynamic Learning Environment). The MEEP accumulates all teaching and methodological support necessary for conducting educational activities.

Lecturers create electronic teaching and learning complexes (ETLC) of disciplines to fill MEEP and provide educational programs with information. An ETLC includes a syllabus and scheduled work program of a subject, an electronic textbook, an electronic summary of 
lectures, electronic tutorials, study guides and dictionaries, reference books, computer tests, etc. The Distance Education Centre of KNUTD has developed methodological guidelines that include step-by-step instructions for implementing the necessary actions in the MEEP for teachers, tutors and students. Appropriate instructions and training are periodically arranged for research and teaching staff.

The improvement of the quality of educational activities of the University is the main advantage of the implemented MEEP. Such a development is caused by the easy accessibility of instructional materials; quick correction and updating of ETLC; convenient search and intelligible structure of ETLC; increased motivation for self-education; increased interest and cognitive activity due to the diversification of forms of students' self-control and selfappraisal.

Maintenance of permanent communication between participants of the educational process demonstrates the effectiveness of MEEP use for all forms of learning, especially for distance learning. Teachers and students can communicate in a web-classroom environment; participate in online seminars (webinars) and online meetings. Students communicate with tutors, supervisors, an administrator-consultant and other members of the group through an online-chat or offline-email. Such tools as graphic chat, forum, bulletin board, testing, etc. are also actively used.

The following shortcomings in the application of MEEP can be noted:

- In most cases, educational materials are presented in rather primitive forms, such as e.g. electronic copies of printed matters;

- Lecturers poorly use MOODLE's resources for statistical analysis of data. For example, they do not usually place feedback on the level of students' mastery of specific topics and/or the regularity and quality of fulfilment of unsupervised works;

- In the course of test design, the vast majority of lecturers use only multiple-choice questions, while MOODLE allows one to develop more than ten types of composite structures for test tasks. This fact significantly limits checking the depth of knowledge acquisition;

- Computer simulations and modelling are almost unclaimed in MEEP. The exception is the organisation of virtual laboratory works based on the ChemLab 2.1 program [14].

The realities of modern education increase the importance of monitoring the quality of educational activities of universities. The automated system for recording academic work of higher education students entitled "Electronic Journal" was developed and implemented to ensure the transparency and objectivity of evaluating the academic performance of students at KNUTD. The purpose of the system is to provide regular diagnostics of learning outcomes and respond promptly to the failure of individual students, formulate information about ultimate control, determine the rating of academic achievements and prepare reports for making managerial decisions on improving the educational process at the university. The users' work is carried out through a web-interface. Such an approach allows one to avoid the installation of specialised software on users' computers and work with the system using any computer connected to the Internet. The development of the server part of the system is made using the PHP programming language and DBMS MySQL. The client interface is implemented using HTML, CSS and JavaScript.

To prevent and detect academic plagiarism in the scientific works of higher education students, the electronic system entitled "Anti-Plagiarism" (software for text analysis) is used at KNUTD. The program was developed by Khmelnitsky National University (KhNU); the agreement between KNUTD and KhNU provides legal use of this system for text analysis. The system has client-server architecture. The server part is hosted on KhNU servers; it allows all users to use a common database. DBMS MySQL is used to store downloaded texts. 
The client part of the software is written in Java.

The electronic system "Rating of RTS" was developed to evaluate the efficiency of research and teaching staff in a reported year. The system is designed using MS Office Excel electronic databases. The RTS rating is an instrument for motivating RTS for active research and publishing activity. The rating indicators are annually corrected to embody the actual needs of KNUTD development, such as strengthening the university's image and gaining higher positions in Ukrainian and world university rankings.

The program complex entitled "The System of Financially-Oriented Management of Higher Education Institutions" is actively used in the organisation of resource support of educational activities at KNUTD. It is intended for automation of the formation, accounting and storage of financial, economic and personnel documentation. Donetsk National University is the developer of this program. Continuous cooperation with the developer allows KNUTD to update the system following changes in legislation and University needs. The system has client-server architecture. DBMS Firebird is used for data management; client software was written for the Windows platform using the .NET Framework and C\# language.

The experience of using the ACS at KNUTD revealed some problems that may arise with the implementation of ICT:

- Lack of sufficient skills of the RTS in working with modern ICT and techniques, and lack of basic computer skills and informational culture of all participants of the educational process;

- Organisational, psychological and pedagogical problems, which are connected with the processes of education, attitude development, management of scholarly activity of the university students as a result of their reduced direct communication with teachers.

Solving these issues is one of the top priorities of institutions of higher education that seek to achieve the competitiveness of their educational services in the European and world markets.

\section{CONCLUSIONSAND OUTLOOK FOR FURTHER RESEARCH}

Functioning of the mechanism of quality assurance of educational activities on the basis of an automated control system in institutions of higher education is a multifaceted task. It includes but is not limited to the following aspects:

- Development of ACS, and recognition of the high responsibility of all participants involved in the educational process for the accuracy and timeliness of information in the system; availability of necessary resources (personnel, financial, material, informational, scientific, educational, etc.);

- The organisation of the educational process that most adequately corresponds to modern tendencies of development of the national and world economy and education;

- Control of the educational activity of an IHE and the quality of training of specialists at all stages and levels of education.

Thus, the application of modern information and communication technologies opens up new opportunities and ways to improve the quality of educational activities, promotes the formation of an internal quality assurance system based on total quality management standards. Such an approach allows rational building of the educational process, managing it more efficiently and comparing the results with the planned goals at all stages of the training. Effective use of automated control systems for educational activities makes it possible to increase the efficiency and quality of the educational process, prepare the younger generation 
for life in the information society, intensify scientific research at educational institutions, improve the efficiency and effectiveness of management of academic units (institutes, faculties, departments, etc.) and educational activities of an IHE as a whole. It promotes the integration of national information educational systems into the global network, which greatly facilitates access to international information resources in the field of education, science, culture and other areas, and develops a modern corporate culture of institutions of higher education.

The development of psychological and pedagogical recommendations, which are aimed at the overcoming of opposition to the implementation of the latest information and communication technologies by research and teaching staff, in particular, by the older generation, and the development of a corresponding motivational system are promising fields for further research.

\section{REFERENCES (TRANSLATED AND TRANSLITERATED)}

[1] O. B. Morhulets, "Management of a Higher Education Institution as a Market Participant: a Monograph". Kyiv, Ukraine: KNUTD, 2017. (in Ukrainian).

[2] I. M. Hryshchenko, T. M. Vlasyuk, and D. A. Makatyora, "Methodical approaches to attractiveness assessment of a higher educational institution", Actual Problems of Economics, vol. 153, no. 3, pp. 155159, 2014. (in Ukrainian).

[3] I. M. Gryshchenko, "Factors enhancing the efficiency of education activity of higher education institutions in Ukraine", Actual Problems of Economics, vol. 177, no. 3, pp. 134-141, 2016. (in Ukrainian).

[4] S. O. Karpliuk, and T. A. Vakaliuk, "Review of Software Functional Opportunities for Managing Educational Process of Higher Education", Informatsiini tekhnolohii i zasoby navchannia, vol. 65, no. 3. pp. 262-276, 2018. [online].

Available: https://journal.iitta.gov.ua/index.php/itlt/article/view/1961/1341.(in Ukrainian)

[5] O. P. Vorobyova, "Quality Assurance of E-learning in the European Higher Education Area", Informatsiini tekhnolohii $i$ zasoby navchannia, vol. 64, no. 2, pp. 245-252, 2018. [online]. Available: https://journal.iitta.gov.ua/index.php/itlt/article/view/1951/1322 (in Ukrainian)

[6] K. Kear, et al.,Quality Assessment for E-learning: a Benchmarking Approach (Third edition). Maastricht: European Association of Distance Teaching Universities, 2016. [online]. Available: http://oro.open.ac.uk/47597/1/E-xcellence_manual_2016_third_edition.pdf. (in English)

[7] T. B. Poyasok, and O. I. Bespartochna, "Arrangement of Pedagogical Interaction Among the Education Process Participants in Computer-Oriented Educational Environment of a Higher Education Institution”, Informatsiini tekhnolohii $i$ zasoby navchannia, vol. 67, no. 5, pp. 199-219, 2018. [online]. Available: https://journal.iitta.gov.ua/index.php/itlt/article/view/2110/1388. (in Ukrainian)

[8] S. V. Petrenko, "Optimization and Analysis of the Results of Using LMS Moodle in the Mixed Learning System in University”, Informatsiini tekhnolohii $i$ zasoby navchannia, vol. 61, no. 5, pp. 140-150, 2017. [online]. Available: https://journal.iitta.gov.ua/index.php/itlt/article/view/1795/1249 (in Ukrainian)

[9] O. Glazunova, O. Kuzminska, T. Voloshyna, T. Sayapina, and V. Korolchuk, "E-environment based on Microsoft SharePoint for the organisation of group project work of students at higher education institutions", Informatsiini tekhnolohii i zasoby navchannia, vol. 62, no 6, pp. 98-113, 2017. [online]. Available: https://journal.iitta.gov.ua/index.php/itlt/ article/view/1837/1283. (in Ukrainian).

[10] V. H. Hrytsenko, "Efficiency Criteria of the Information-Analytical Control System Creation and Implementation in the University Educational Process", Informatsiini tekhnolohii $i$ zasoby navchannia, vol. 61, no. 5, pp. 233-244, 2017. [online]. Available: https://journal.iitta.gov.ua/index.php/itlt/article/view/1805/1251. (in Ukrainian)

[11] O. S. Tovkanets, "Strategic Directions of Information and Communication Technologies Development in the High European School at the Beginning of the XXI Century", Informatsiini tekhnolohii $i$ zasoby navchannia, vol. 66, no. 4, pp. 14-23, 2018. [online]. Available: https://journal.iitta.gov.ua/index.php/itlt/article/view/2118/1369. (in Ukrainian)

[12] O. B. Morgulets, "Modernizationofuniversitymanagementsystem", Bulletin of KNUTD, Series: Economics, Special Issue: Effectiveness of Organizational and Economic Mechanism for Innovative Development of Higher Education: Materials of the VII International Scientific and Practical Conference (October 6, 2017, Kyiv), pp. 389-395, 2017. (in Ukrainian). 
[13] University of Economics and Trade. [online]. Available: http://www.izeta.puet.edu.ua(in Ukrainian). Accessed on: January 08, 2019. (in Ukrainian).

[14] T. M. Derkach, "Theoretic and Methodological Basics of Training of Future Specialists of Chemical Specialities Using Information Technology". Dnipropetrovsk, Ukraine: Art-Press, 2013. (in Ukrainian).

Text of the article was accepted by Editorial Team 21.01.2019

\title{
ІНФОРМАЦІЙНО-КОМУНІКАЦІЙНІ ТЕХНОЛОГІЇ УПРАВЛІННЯ ЯКІСТЮ ОСВІТНЬОЇ ДІЯЛЬНОСТІ УНІВЕРСИТЕТУ
}

\author{
Моргулець Оксана Борисівна \\ доктор економічних наук, професор кафедри підприємництва та бізнесу, \\ директор навчально-методичного центру управління підготовкою фахівців КНУТД \\ Київський національний університет технологій та дизайну, м. Київ, Україна \\ ORCID ID 0000-0001-6530-1478 \\ morgulets_oks@ukr.net
}

\section{Деркач Тетяна Михайлівна}

доктор педагогічних наук, завідувач кафедри професійної освіти в сфері технологій та дизайну Київський національний університет технологій та дизайну, м. Київ, Україна

ORCID ID 0000-0003-1087-8274

derkach.tm@knutd.edu.ua

\begin{abstract}
Анотація. У статті висвітлені результати практичного застосування сучасних інформаційно-комунікаційних технологій в управлінні закладом вищої освіти на прикладі Київського національного університету технологій та дизайну (КНУТД). Розглянуто складові елементи системи управління якістю освітньої діяльності. Охарактеризовано та проаналізовано підсистеми автоматизованої системи керування освітньою діяльністю університету. Ключовими елементами застосовуваних інформаційних систем $є$ такі електронні бази даних: контингент студентів та їх академічна успішність; результати працевлаштування та задоволення студентів освітніми програмами; планування й облік навчального навантаження; ефективність роботи викладачів; облік навчально-методичних ресурсів, матеріально-технічне оснащення та його вартість; інші показники діяльності університету. Крім упроваджених загальновідомих пакетів прикладних програм, таких як iZETA, «Система фінансово-орієнтованого менеджменту закладів вищої освіти», «AntiPlagiarism», охарактеризовано програмні продукти власної розробки КНУТД. А саме, пакет «Розклад», за допомогою якого формуються довідники, що містять дані для складання розкладу занять, з доступом до них у всіх підрозділах. «Електронний журнал» забезпечує моніторинг результатів навчання та оперативне реагування на неуспішність окремих студентів, послуговує для формування відомостей підсумкового контролю та визначення рейтингів академічної успішності здобувачів вищої освіти тощо. Електронну систему «Рейтинг НПП» використовують для оцінювання діяльності науково-педагогічних працівників за результатами роботи у звітному році. Описано модульне середовище освітнього процесу університету, що працює на базі платформи дистанційного навчання Moodle. Воно акумулює навчально-методичне забезпечення, необхідне для провадження освітньої діяльності. Результати дослідження мають практичну цінність, оскільки впровадження розглянутих програмних продуктів спроможне підвищити якість та ефективність управління освітньою діяльністю закладів вищої освіти.
\end{abstract}

Ключові слова: інформаційно-комунікаційні технології; автоматизована система керування;система управління якістю; заклад вищої освіти; система забезпечення якості освітньої діяльності; управління якістю освіти.

\section{ИНФОРМАЦИОННО-КОММУНИКАЦИОННЫЕ ТЕХНОЛОГИИ УПРАВЛЕНИЯ КАЧЕСТВОМ ОБРАЗОВАТЕЛЬНОЙ ДЕЯТЕЛЬНОСТИ УНИВЕРСИТЕТА}




\title{
Моргулец Оксана Борисовна
}

доктор экономических наук, профессор кафедры предпринимательства и бизнеса, директор учебно-методического центра управления подготовкой специалистов КНУТД Киевский национальный университет технологий и дизайна, г. Киев, Украина ORCID ID 0000-0001-6530-1478 morgulets_oks@ukr.net

\section{Деркач Татьяна Михайловна}

доктор педагогических наук, заведующая кафедрой профессионального образования в сфере технологий и дизайна Киевский национальный университет технологий и дизайна, г. Киев, Украина ORCID ID 0000-0003-1087-8274

derkach.tm@knutd.edu.ua

\begin{abstract}
Аннотация. В статье освещены результаты практического применения современных информационно-коммуникационных технологий в управлении учреждением высшего образования на примере Киевского национального университета технологий и дизайна (КНУТД). Рассмотрены составляющие элементы системы управления качеством образовательной деятельности. Охарактеризованы и проанализированы подсистемы автоматизированной системы управления образовательной деятельностью университета. Ключевыми элементами применяемых информационных систем являются следующие электронные базы данных: контингент студентов и их академическая успеваемость; результаты трудоустройства и удовлетворенности студентов образовательными программами; планирование и учет учебной нагрузки; эффективность работы преподавателей; учет учебно-методических ресурсов, материально-технического оснащения и его стоимость; другие показатели деятельности университета. Кроме внедренных общеизвестных пакетов прикладных программ, таких как IZETA, «Система финансовоориентированного менеджмента учреждений высшего образования», «Anti-Plagiarism», охарактеризованы программные продукты собственной разработки КНУТД. В частности, пакет «Расписание», с помощью которого формируются справочники, содержащие данные для составления расписания занятий, с доступом к ним во всех подразделениях. Программа «Электронный журнал» обеспечивает мониторинг результатов обучения и оперативное реагирование на неуспеваемость отдельных студентов, служит для формирования ведомостей итогового контроля, определения рейтинга академической успеваемости соискателей высшего образования и тому подобное. Электронную систему «Рейтинг НПР" используют для оценки деятельности научно-педагогических работников по результатам работы в отчетном году. Описана модульная среда образовательного процесса университета, работающая на базе платформы дистанционного обучения Мoodle. Она аккумулирует учебно-методическое обеспечение, необходимое для осуществления образовательной деятельности. Результаты исследования имеют практическую ценность, поскольку внедрение рассмотренных программных продуктов способно повысить качество и эффективность управления образовательной деятельностью высших учебных заведений.
\end{abstract}

Ключевые слова: информационно-коммуникационные технологии; автоматизированная система управления;система управления качеством;учреждение высшего образования;система обеспечения качества образовательной деятельности; управление качеством образования.

\section{(c) BY-NC-SA}

This work is licensed under Creative Commons Attribution-NonCommercial-ShareAlike 4.0 International License. 